Liliana Sikorska

Nineteenth- and Twentieth-Century Readings of the Medieval Orient 
Research in Medieval

and Early Modern Culture XXXII

Studies in Medieval

and Early Modern Culture LXXX 


\section{Liliana Sikorska}

Nineteenth- and

Twentieth-Century

Readings of the

Medieval Orient

Other Encounters 
ISBN 978-1-5015-1791-4

e-ISBN (PDF) 978-1-5015-1336-7

e-ISBN (EPUB) 978-1-5015-1310-7

\section{Library of Congress Control Number: 2021948062}

\section{Bibliographic information published by the Deutsche Nationalbibliothek}

The Deutsche Nationalbibliothek lists this publication in the Deutsche Nationalbibliografie; detailed bibliographic data are available on the Internet at http://dnb.dnb.de.

(c) 2021 Walter de Gruyter GmbH, Berlin/Boston

Cover image: Aleksander Laszenko (1883-1944). Brama w Sidibel Abbes [The Gate in Sidibel Abbes], color woodcut, 1932. From the author's own collection; $17^{\text {th }}$-c. Turkish brass plate. From the author's own collection; Translation into Arabic: Dr. Filip Andrzej Jakubowski; Preparatory cover version: Mr. Jakub Grabowski Typesetting: Integra Software Services Pvt. Ltd. Printing and binding: $\mathrm{CPI}$ books $\mathrm{GmbH}$, Leck

www.degruyter.com 
For Jacek, forever and beyond and for my friends who were with me through thick and thin 
